\title{
Tienviitta merkitty - itse tie jää loppuunkulkematta
}

\section{Lyyli Ronkonen ja Igor Skripjuk 1994. The Problem of Personality in Soviet and Russian Pedagogics. Research Project Personality as an Educational Phenomenon by professor Erkki A. Niskanen. Research Bulletin 86, Department of Education. University of Helsinki.}

Kirjoituksen aihe, "Persoonallisuuden ongelma neuvostoliittolaisessa ja venäläisessä kasvatustieteessä" on ajankohtainen ja merkittävä ja sen esiintuoma ongelma monimutkainen ja monitahoinen ajatellen tieteen eri kausia sekä niitä tieteellisiä koulukuntia ja virtauksia, jotka ovat työskennelleet ja työskentelevät kysymyksen parissa. Aiheen kärkevyys ja ajankohtaisuus korostuvat erityisesti välttämättömyydestä luoda lähestymistapa käsitellä PERSOONALLISUUTTA, kun jälkineuvostoliittolaisessa yhteiskunnassa vanha ja uusi törmäävät yhteen ja konseptio itsestään yhteiskunnasta itse asiassa puuttuu.

Tekijät ovat nähneet suuren vaivan analysoidessaan ja muokatessaan tieteellistä aineistoa, jota heidän artikkelissaan on käytetty. Silti on todettava, että kirjoittajien siteeraama tekijäpiiri ei heijasta likikään kattavasti kasvatustieteen ja psykologian kyseisiä alueita. Pois ovat jääneet mm. sellaiset nimet kuin E.V. Iljenkov, M.K. Mamardashvili, I.S. Kon, Makarenko ja Suhonilimski.

Kirjoittajat ovat epäilemättä onnistuneet sekä yleisessä ongelmanasettelussa että otsikoinnissa kysymyksenasettelun edellyttämien teemojen osalta. Lukija saa siten artikkelin luettuaan tietoa persoonallisuuden problematiikasta neuvostoliittolaisessa ja venäläisessä tieteessä (kasvatustieteessä, psykologiassa ja filosofiassa) sekä nykytilanteesta tarkasteltavan kysymyksen osalta. juuri otsikko antaa ymmärtää, että lukija kenties löytäisi vastauksia persoonallisuutta koskeviin kysymyksiin, jotka väistämättä nousevat esiin nimenomaan yhteiskunnan konseption vaiheessa oli kysymys sitten kapitalistista, sosialistisesta tai demokraattista yhteiskunnasta.

Kirjasella on arvoa myös siinä mielessä, että se tuo länsimaiselle tiedeyhteisölle tutuksi venäläisiä kasvattajia sekä muutamia venäläisiä ja neuvostoliittolaisia psykologeja.

Kirjasen yleisen suunnalta on kuitenkin todettava, että siitä puuttuu ongelman "henki", ikäänkuin ei olisi ollutkaan erilaisia lähestymistapoja, kuten toiminnallinen, kulttuurihistoriallinen jne. tai ei olisi ollutkaan koulukuntien, suuntausten ja virtausten välistä taistelua, vuoden 1936 asetusta "Pedagogisista vääristymistä", psykoanalyysin katoamista, taistelua kosmopolitismista. Liioin ei näy tekninen edistyminen, kuten radion, television ja tietokoneiden ilmaantuminen eikä probleemeja niiden vaikutuksesta ihmiseen.

Kiinnitän huomiota tekijöiden määrätynlaiseen epätarkkuuteen kirjasta kirjoitettaessa:

Sisältö on valitettavasti ristiriidassa paljon lupaavan otsikon sekä mielenkiintoisten alaotsikoiden kanssa. Kysymyksenasettelun painopiste kirjasen otsikossa "Persoonallisuuden ongelma neuvostoliittolaisessa ja venäläisessä kasvatustieteessä" määrittelee sisältösuunnitelman kronologian ja edellyttää aiheen käsittelyä kolmessa tai ainakin kahdessa kronologisessa aikajaksossa (joko venäläinen, neuvostoliittolainen ja venäläinen/jälkineuvostoliittolainen tai neuvostoliittolainen ja venäläinen, ts. jälkineuvostoliittolainen). Tekijät ovat rajoittuneet kuitenkin kahteen ensimmäiseen, siis ennen sosialismia edeltäneeseen yhteiskuntaan ja neuvostoliittolaiseen rikkoen 
siten oman otsikkonsa asettaman kronologian. Näin ollen otetun teeman kärkevyys heikkenee ja edessä on kirjoitus, joka on referaatinomainen, pääosin neuvostokauden kirjallisuutta koskeva yhteenveto. Nykypäivään kantavaa historiallista ulottuvuutta ei problematisoida.

Otsikko edellyttää persoonallisuuden tarkastelemista kasvatustieteessä, ts. kasvatustieteellisestä näkökulmasta ja kasvatustieteen alueella (teorioiden, konseptioiden, lähestymistapojen, sosiaalisten tilausten, mallien ja ongelmien puitteissa). Kuitenkin kysymyksen tarkastelu suoritetaan toisen tieteen, psykologian, alueella. Kasvatustieteen tulisi olla kirjasen teemana, mutta sana pedagogiikka esiintyy artikkelissa vain kolme kertaa ja katoaa seuraavan lauseen mukana:

"But the pedagogical approach is in reality an integrated formation, re-producing in some respect psychological and social psychological interpretations of the personality problem. As it is, the pedagogic approach will not be discussed separately. The more attention will be given to the psychological perspective on the problem of "Personality." (s. 9).

Otsikossa mainittu persoonallisuuden "ONGELMA" ei avaudu - käsite jää kirjoittajien huomion ulkopuolelle ja sisällöllisesti keskuspaikan valtaa käsite persoonallisuus ja sen määrittely kirjallisuudessa. Luonnollisestikin joitakin mielenkiintoisia ongelmia nousee juuri näiden määritelmien pohjalta alkaen vaikkapa käsitepareista "persoonallisuus - naamio" tai "yksilö - persoonallisuus" ja niiden suhteista ja korrelaatioista. Kaikissa yhteiskunnissa on samalla tavoin kysymys naamioista, rooleista tai yksilön ja yhteisön suhteista, mutta aivan erityisesti Neuvostoliitossa ja sitä seuranneessa yhteiskunnassa.

Artikkelin kirjoittajien varomattomuutta on myös ylenmääräinen kiinnostus B.V. Shorohovin kirjoitukseen "Tendenssit persoonallisuuden tutkimuksessa neuvostopsykologiassa" (ilmestynyt teoksessa Persoonallisuuspsykologian ongelmia. Neuvostoliittolais-suomalainen symposiumi. Nauka. Moskva 1982. ss. 11-23) ja runsas lainausten käyttö tästä kirjoituksesta, usein ilman lainausmerkkejä.

Yhteenvetona haluan todeta, että kirjoittajien muotoilemat kysymykset, joihin he suurimmalta osalta eivät anna vastausta, herättävät ajatuksia ja ovat tavattoman ajankohtaisia ja kiintoisia. $\mathrm{Ne}$ voisivat todellakin antaa aiheen kirjoittaa artikkeli, jossa tällä tai toisella tasolla selvennettäisiin ja kehiteltäisiin problematiikkaa, jonka artikkelin kirjoittajat ovat onnistuneesti osoittaneet.

Dmitri Lioubich 